\title{
Group Resume Learning through Drama in Instructional Technology Course
}

\author{
Artina Diniaty ${ }^{a, *}$, Lina Fauzi'ah ${ }^{a}$ \\ ${ }^{a}$ Department of Chemistry Education, Islamic University of Indonesia \\ ${ }^{*}$ Corresponding author: artina.diniaty@uii.ac.id
}

\begin{abstract}
The implementation of group resume learning through drama in instructional technology subjects aimed to create a pleasant atmosphere and improve student creativity in learning so as to facilitate them in understanding the material being studied. The implementation of the research was conducted in four stages: plan, implementation, observation, and evaluation. The results showed that 1) the assessment of drama on group resume learning through drama in instructional technology course is very good, and 2) student response to group resume learning through drama in instructional technology course is very good.
\end{abstract}

Keywords: Group resume, drama, Instructional technology

\section{INTRODUCTION}

Learning was an interaction between educators and learners to exchange information in a learning environment. Learning was done to achieve certain goals. Therefore, learning could not be separated from several components that support it, including learning strategies, learning models, learning resources, and learning media. Some of these things determined the effectiveness and efficiency of a learning process undertaken in order to achieve the objectives of the learning itself. Information/materials in a learning usually consist of concepts and theories that must be understood by learners. The number of concepts and theories that must be understood learners sometimes lead learners to have difficulty in learning it. No exception to the Instructional Technology course which was one of the subjects in Department of Chemistry Education which studies the role of learning technology in teaching and learning; theory of teaching and learning; the foundation of educational technology; strategies, approaches, models, and methods of learning; media position in learning and taxonomy of instructional media; the use of ICT in learning, and communication in learning. The material studied in the course was quite a lot, so it may be difficult to be understood by students. Therefore, need appropriate strategies to be applied in the learning process so that students easily understand the material learned and the atmosphere of learning to be fun so that the purpose of the instructional technology courses could be achieved effectively and efficiently. One of the strategies that can be applied was group resume. Group resumes were included in a fun active learning strategy through activities undertaken in a group [1]. Active learning was indispensable for the students because the active learning, students can more easily absorb everything they learned. In addition, the pleasant atmosphere in learning also supported students in understanding the material being studied. Therefore, group resume learning through drama becomes an option to be applied in the learning process of instructional technology course. Group resume learning through this drama was expected to create a pleasant atmosphere in learning so as to facilitate students to understand the material learned.

\section{RESEARCH METHODS}

The research was a quantitative descriptive research. Stages in the study included the planning, implementation, observation, and evaluation. Activities were undertaken at each stage, among others as follows:

1. Planning

2. The activities in this planning stage were devise the learning device suitable for use in group learning through drama resumes.

3. Implementation

4. Activities at the stage of implementation was an activity to carry out learning with group resume through drama as planned. 
5. Observation

6. Activity at the observation stage was an activity observing student activities during the learning process with group resume through drama.

7. Evaluation

8. Activities at the evaluation stage was an activity to process data obtained from observations during the learning process with group resume through drama.

This research was conducted on students of Department of chemistry education of UII 3rd semester. The data obtained from this research included drama assessment data and student response result data on group resume learning through drama. The instrument used to collect data consists of drama observation sheet covered aspects of the property, setting, plot, characterization, and story and student response questionnaire on group resume learning through drama covered aspects of motivation, personal skills, and social skills. Analysis of the data used can be seen in Table 1.

TABLE 1. Technique of Analysis Data

\begin{tabular}{cc}
\hline Range of Score & Category \\
\hline$X>M+1,5 S D$ & Very Good \\
$M<X \leq M+1,5 S D$ & Good \\
$M-1,5 S D<X \leq M$ & Poorly \\
$X \leq M-1,5 S D$ & Not Good \\
\hline
\end{tabular}

\section{RESULTS AND DISCUSSION}

Group resume learning through drama had the goal of creating a fun atmosphere and improving the creativity of students in learning so that they were easy to understand the material being studied. The implementation of group resume learning through drama covered several stages, including:

1. Lecturer delivered learning materials

2. The learning material that is delivered was the existing material in the instructional technology course.

3. Students were divided into 4 groups, each group consists of 10-11 students

4. Each group consists of a large number of students to make it easier for students to plan the drama that will be displayed in the classroom.

5. Each group was asked to discuss the instructional material given by the lecturer and then plan the presentation in the form of drama

6. Students in the group discussed all the material they have learned and then plan the presentation in a drama that would be shown in the class as a result of their discussion.

7. Each group presented the results of their discussions through drama performances

8. Each student in the group followed the appropriate drama performances they had planned.

9. All students did class discussions

10. Students responded to drama performances conducted by each group and then discussed in the classroom related to the material delivered through the drama.

11. The lecturer gave confirmation of the result of the class discussion

12. Lecturers gave reinforcement of the results of the discussion in the form of more detailed explanation related to the learning that has been done and gave a positive response to all students who participate actively in the learning process

13. Students concluded the learning outcomes

14. All students concluded the learning outcomes that have been done. Hopefully, all students can understand all the material they have learned.

The results of the drama assessment in group resume learning through drama can be seen in Figure 1. 


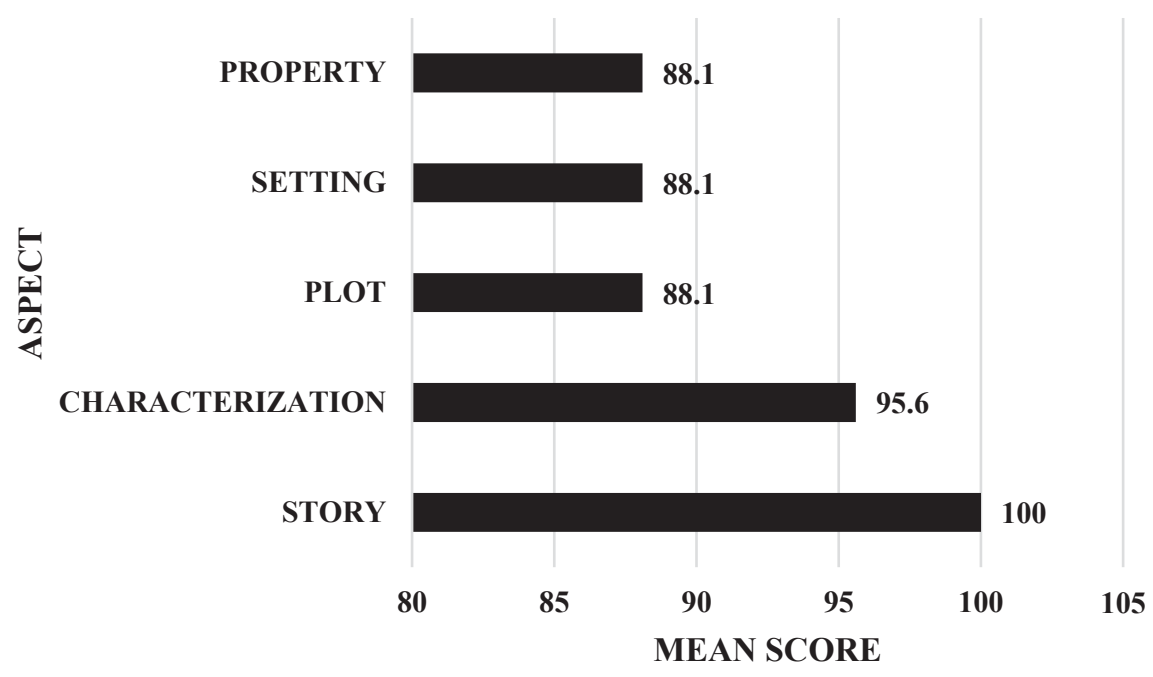

FIGURE 1. The results of the drama assessment in group resume learning through drama

Based on the results of the drama assessment presented in Figure 1., it could be seen that for the whole aspect of getting the category of value was very good. Aspects of the story get a value of 100 , meaning percent achieved is $100 \%$ achievement. This means that the story in the drama corresponds to the learning material, the material delivered through the drama was true and easily understood by the students. Drama learning is a learning with storytelling patterns by taking the theme according to the daily life of the students so as to make the learning atmosphere feel fun and dynamic [2]. The creation of a fun and dynamic learning atmosphere made the students become more interested in learning so that the material learned can be easily understood by them. Students were required to present the material they learned and discussed in a group through a work of drama. The drama featured also was required them to work together so that the material delivered through the drama can be easily understood by other students. They must be able to understand the material they have learned in advance to be able to explain it to others through the drama they perform. Learning through drama also improves students' creativity in learning. Students were becoming easier and confidence in expressing all the ideas they have [8].

The result of student response to group resume learning through drama was presented in Figure 2.

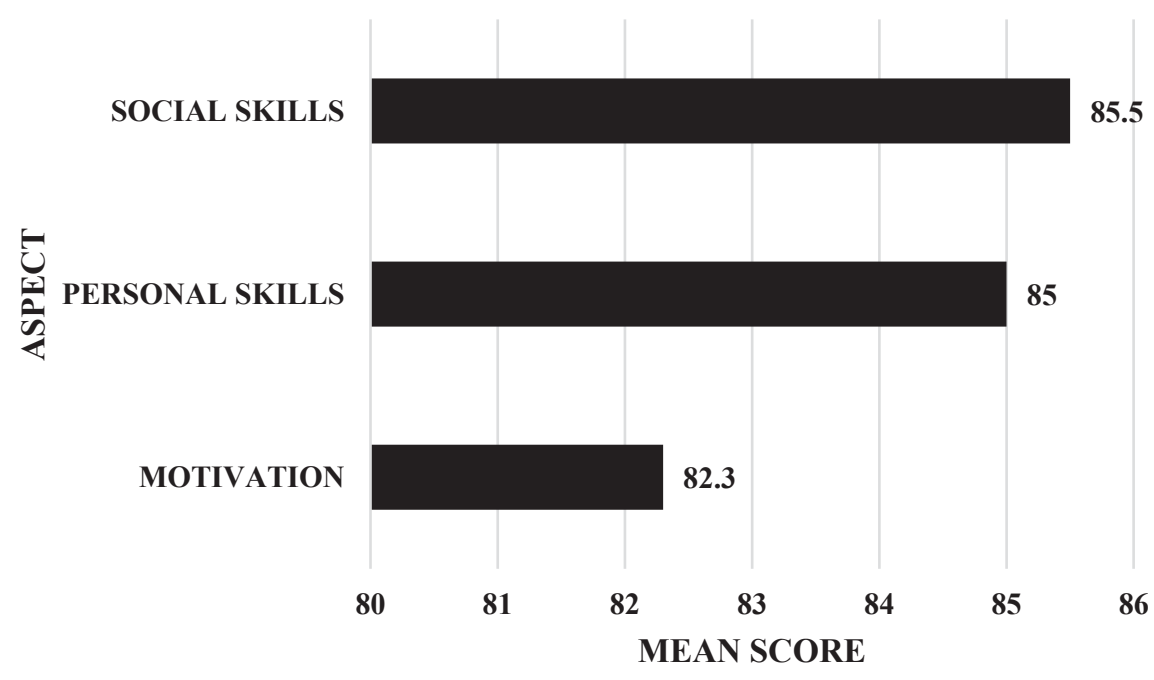

FIGURE 2. The Result of Students Responses 
Based on the result of the student's response to the group resume study through the drama presented in Figure 2., it can be seen that all aspects got a very good category. This means that the group resume learning enabled the students to participate actively in learning, more creatively, learns to work with others, to respect the opinions of others, more confident in expressing their opinions and ideas, and more enthusiasm for learning. In line with this, group resume learning had advantages, among others, 1) to make interaction and familiarity among students better, 2) to familiarize students to listen to the opinions of others, although different from his opinion, 3) can grow a competitive culture among students because psychologically students have high motivation to perform well individually and have emotional involvement to maintain the solidarity of group familiarity when conveying the outcome of the discussion [1]. This group resume learning was included in active learning. The use of learning strategy becomes important because it can simplify the learning process, which means easier for students in understanding the subject matter because each learning strategy was designed to facilitate the learning process [3] [4]. Active learning was a process that involves students to perform an action and give them the opportunity to think about all they do [5]. Group resume learning through drama made students learn actively. Active learning was needed by students in order to get maximum results in learning. This was because passive students would receive just the learning materials from the lecturers, so there was a tendency to more quickly forget the material they have learned [6]. While active students would be easier to remember learning materials as they were involved in the learning process [8]. Activeness of students made the learning process more effective so that it made they able to remember the learning materials in the long term [5].

The basic elements in improving active learning one of them were to make students able to speak and hear [9]. Speaking and listening in the classroom was an active learning process that aims to clarify students' thinking as well as to practice skills expressing their own ideas [5]. Group resumes learning through drama cannot be separated from the activities of speaking and listening. Therefore, group resume learning through drama could train students to be skilled at speaking and listening. Group resume learning through drama can also enhance cooperation [7]. Cooperation was shown from the planning stage to the discussion phase of the learning outcomes in the classroom [10].

\section{CONCLUSION}

Group resume learning through drama in the instructional technology course enabled students to participate actively in learning, more creatively, learns to work with others, respect each other's opinions, more confident in expressing their opinions and ideas, and more enthusiasm for learning. The result of the drama assessment on group resume learning through drama on the instructional technology course is very good. The student's response to the application of group resume learning through drama on the instructional technology course is very good.

\section{REFERENCES}

1. Isjoni, Alfabeta, 3, 96-104 (2010).

2. M. Silberman, Active Learning: 101 Cara Belajar Aktif (Nuansa Cendekia, Bandung, 2013).

3. Y. D, Pena, 3, 1, 51-66 (2013).

4. Y. Dewi, Model-model Pembelajaran Inovatif (FKIP Universitas Jambi, Jambi, 2010).

5. Munawaroh, J P K I, 4, 1, 7-14 (2015).

6. H. Zaini, M. Bermawy, dan A. A. Sekar, Strategi Pembelajaran Aktif (CTSD, Yogyakarta, 2007).

7. D. A. Sugesti, J T P, 1, 1-15 (2016).

8. K. Covell, J. McNeil, And R. B. Howe. Sch. Psychol. Int. 30, 282-290 (2009).

9. S. W. Cawthon, K. Dawson, and S. Ihorn, J. Learn. Arts. 7, 1, 1-29 (2011).

10. I. Archambault, M. Janosza, J. Fallu, and L. S. Pagania J. Adolesc. b, 651-670 (2008). 